\title{
Modeling the Relationship of Consumer Engagement and Brand Trust on Social Media Purchase Intention - A Confirmatory Factor Experimental Technique
}

\author{
Vipin Jain, Mredu Goyal, Manvinder Singh Pahwa
}

\begin{abstract}
Today's marketing landscape is characterized by social media proliferation. This impels companies to adapt such advertising strategies that engage with the audience in their predominantly used medium. Appertaining to the cogitation, the empirical study endeavours to identify the relationship of consumer engagement and brand trust on purchase intention through advertisement on social media. Besides, it also aspires to explore the mediation effect of performance expectancy on brand trust and purchase intention.
\end{abstract}

A model designed was tested using the Structural Equation Modeling (SEM). A structured questionnaire was prepared and administered to 542 respondents, selected by judgemental sampling method of which 482 were found valid and hence considered for model development. The conclusions of the research study suggests empirical implications for an effective advertising strategy on social media.

Keywords : Advertising Strategy, Structural Equation Modelling, Performance Expectancy, Trust, Purchase Intention.

\section{INTRODUCTION}

The enfeebled traditional media techniques are consistently evoking organizations to swing towards the new media for spreading news about their organizations in an amusing and attractive format(Hanke, 2015). Subsequently, Social media has been developed as an inimitable imperative channel of digital marketing. It allows instant reach to worldwide customers(Nelson, 2018) as well as comforts marketers to advertise in a stress-free and profitable manner.

This trend towards the new media has transposed the balance of power among thebrand and consumer.The contemporary empowered consumers are able to create content which can be gobbled up by anyone on the globe via different social media channels like Blogs, Pinterest, Twitter or Facebook, etc. The sharing of consumers brand experiences on a public platform also shapes the insights of other consumers towards the brand. Thus, inactivity of the brandon social media as well as unavailability of brands viewpoint will make consumers to rely on third parties thus awarding them more credibility(Hollebeek, et al., 2014). Hence, if it is not part of the dialogue then such brand's sustainability may become

Revised Manuscript Received on September 22, 2019.

* Correspondence Author

Dr Vipin Jain, Professor, Teerthanker Mahaveer University, Moradabad.

Mredu Goyal, Assistant Professor, Bhartiya Skill Development University, Jaipur

Dr. Manvinder Singh Pahwa, Senior Associate Professor, Manipal University Jaipur

questionable.

The technique, place and time of brands engagement with customers have changed considerably. Consumers are now making their experiences and feedbacks socially available, about goods or services of companies and brands they used. The consumers has always trusted the referrals of their friends or knowns and the new media marketing has this advantage. Accordingly, modern net-savvy consumers, now turn towards their friends or peers reviews unlikely other traditional mediums which were endorsed by brand ambassadors, before making any purchase decisions.

Thus, the critical point of an effective marketing strategy for any brand is to mark their constant presence on the media where customers are spending most of their time.

Adaption of the brand marketing strategies in favour of the new trend will only help to succeed in this hyper-connected environment. Thus, it is vital to engage with the consumers on the platforms they are mostly active and that are varioussocial media platforms such as Facebook, YouTube, Instagram, etc. Therefore, an effective strategy augments a brand page in such a way that enhances consumer brand trust byfunctioning as an endorsement letters for them(Bhargava, 2006).

Individual and his environment is the focal point on social media marketing. Hence, an effective strategy is to focus on understanding when, where and how to engage with this target group. To penetrate in this loop of engagement, it is critical to develop brandtrust. Consumer engagement through social media gives birth to dialogue. This dialogue generates brand trust among the consumers. Besides this the brand has an opportunity to fetch itself with the valuablefeedback of its consumers on its actions and products through engagement. And these insights can be used effectively in formulating various strategies.

Thus, the whole strategies on social media revolves around the engagement of audience process. This shows that the brands are no longer concerned about awareness else the brand engagement is their priority and a new trend. Customer engagement is the ultimate goal and is the condition where customers at the highest level of emotional involvement which naturally results in commitment(Roberts \& Alpert, 2010). This in turn results in purchase intention exhibiting brand advocacy and unconditional loyalty. It induces trust of consumers towards the brand and enhances their performance expectancy and helps in improving the bottom line of the company(Reichheld, 2006) 
Based on this contemplation, the researchers have developed a process model which is further tested by using an Structural Equation Modelling.

The study endeavours to identify the relationship among factors affecting consumer purchase intention through social media marketing and tries toexplore the answersof the following research questions:

1. Is there any relationship of factors (engagement / performance expectancy / trust) influencing consumer purchase intent on social media?

2. Does engagement of consumer on social media affects their trust on brand?

3 . Is there any mediating role of performance expectancy on trust in relation to purchase intention?

The following research objectives were derived on the basis of above questions.

1) To determine the influence of social media advertising on purchase intent.

2) To examine the relation between consumer engagement and trust on brand.

3) To identify the mediating effect, if any, of performance expectancy of Facebook brand fan pages on trust in relation to consumer purchase intent.

\section{REVIEW OF LITERATURE AND HYPOTHESIS DEVELOPMENT}

\section{1) Engagement on social media}

Social media provides a connect with peers and assists in effectively assessing the information. Thiscontributes to the trust(Ferik, 2009) andultimately result in developing strong relations among the company and customers. It provides various benefits to brands, like it augments the popularity(De et al., 2012), spread e-WOM(Chen, et al., 2011), share insights and information ( $\mathrm{Lu} \&$ Hsiao, 2010)as well as engenders consumer support(Ali, 2011)(Ballantine \& Stephenson, 2011). All these are possible through an effective engagement strategy. High engagement levels enhances the brand trust(Chaudhuri \& Holbrook, 2001)(Swaminathan, et al., 2007)(Linlin, et al., 2018) as users gradually start feeling themselves as a part of brand (Benson, et al., 2010)(Yoo, 2012). Thus, customer engagement is a key componentof social media marketing strategy (Victor \& J. W. , 2016)The consequential hypothesis formulated is:

$\mathrm{H}_{01}$ : Consumer engagement is positively related to brand trust.

\section{2) Brand Trust}

Trust gained with consumer interaction on social networkingwebsites helps to enhance brand profit (Angella Jiyoung Kim, 2010)(Tan Pei Kian, G. H. , 2017)(Chaudhuri \& Holbrook, 2001). Consumer prefers to purchase with trusted online vendors as per their credibility and benevolence (Ba \& Pavlou, 2002). Absence of trust forestall purchase intention as well as induces misunderstandings among them(Lee \& Song, 2013)(Castaldo, et al., 2010). Hence, it is one of the most critical factor affecting purchase decision-making, as sharing information demands trust among messengers (Liu \& Guo, 2017).

Hence, the proposed hypothesis is:

$\mathbf{H}_{02}$ : Trust on brand is positively related to customer purchase intent.

On immense review of literature revealed that their is existence of interrelations between trust and performance expectancy (Lee \& Song, 2013)(Guo \& Barnes, 2007). Thus, there is same factor loadings of both trust as well as performance expectancy(Ba \& Pavlou, 2002)(Mayer, et al., 2011)(Pavlou, 2003)(McLeod, et al., 2008).

Trust is a critical component for customer engagement and online purchase intention(Chahal \& Rani, 2017) as it moderates the effect of consumer performance expectancy( Sanzo, et al., 2012)(Riemenschneider, 2009). Their is positive correlation between trust and perceived usefulness, besides trust upsurges certain attributes of it(David, et al., 2008). Hence, the following hypotheses is formed:

$\mathrm{H}_{03}$ : Trust on brand is positively related to performance expectancy of social media brand pages.

$\mathrm{H}_{04}$ : Performance expectancy of social media brand pages mediates the relation between trust and consumer purchase intent.

\section{3) Performance Expectancy $(P E)$}

Easier interconnectivity and participation is the blessings of Web 2.0 for its users(Mueller, et al., 2011). But the adoption of these new systems will be more progressive if the individuals perceive them as more fecund, functional, and saves their time as well as effort(Alalwan, et al., 2016)(Venkatesh, et al., 2012)(Venkatesh, et al., 2003)(Shareef, et al., 2017). The positive perception of social media users towards these ads results in dedicated involvement and favourable intentions(Chang, et al., 2015)(Rana, et al., 2016). One more research by (Kim, et al., 2016)supports thesignificance of Performance expectancy to both customersperception as well as their purchase intention. Accordingly, the hypothesis is :

$\mathrm{H}_{05}$ : Performance expectancy of social media brand pages will positively affects customer purchase intent.

\section{EMPIRICAL STUDY}

To achieve the purpose of the research, only Facebook is taken as a scope of study because, it isby far the leading social network in the world(Anon., 2017) and India has maximum number of Facebook users as of October 2018 (statista, 2018). To validate the hypothesized relationships among the constructs, only the users of Facebook who were also following any brand page on the platform, were considered in the study. They were identified using judgmental sampling procedure from the entire Rajasthan, India.The review of literature assisted in formulation of a structured questionnaire on five-point Likert scale.The millennials were the targeted respondents as generation $\mathrm{Y}$ is reported as very tech-savvy and active on social media (EY, 2016)(Rauniar, et al., 2014)(Victor A. Barger, 2016)(Zhang, et al., 2014)(Balakrishnan \& Manickavasagam, 2013)(Bolton, et al., 2013). 542 responses were received and 482 responses were found accurate for analysis after data cleaning.

\section{Measurement model}

A questionnaire was prepared after identifying various elementsof social media advertisements impacting the consumer purchase intent and again comprehending it on the basis of review of literature. The questionnaire comprised of two sections. Firstly, consisteddemographic details of the respondents in terms of their gender, educational qualifications and age as well as 
information if they are a follower of any company on Facebook or not.

The secondsection comprised of 16 statementsrelated to all the four factors/constructs taken for the study. The responses were solicited on five-point likert scaledepending upon the level of agreement ( 1 being "highly agree" to 5 being "highly disagree").

The study derives three items relating to engagement from (Victor A. Barger, 2016)(Linlin, et al., 2018)(Rauniar, et al., 2014).Three statements for trust were adapted from(Wang \&
Gulara Abdullayeva, 2011); another six statementsfor performance expectancy were modified from scale developed (Venkatesh, et al., 2012) and (Alalwan, 2018). The questions for purchase intension were derived and modified from(Venkatesh, et al., 2012)(Rauniar, et al., 2014)(Alalwan, 2018)(Mueller, et al., 2011)(Duffett, 2015).

Table I displays the development and summary of measurement scales.

Table I (Scale Development )

\begin{tabular}{|c|c|c|c|c|}
\hline S.No. & Constructs & Statements & Sources & $\begin{array}{l}\text { Cronbach's } \\
\text { Alpha }\end{array}$ \\
\hline \multirow[t]{4}{*}{1} & \multirow[t]{4}{*}{ Engagement } & $\begin{array}{l}\text { The content of different Facebook brand } \\
\text { pagesinduces me to react (like or dislike } \\
\text { or love or angry, etc.). }\end{array}$ & \multirow[t]{4}{*}{$\begin{array}{l}\text { Review of Literature(Victor A. } \\
\text { Barger, 2016)(Linlin, et al., } \\
\text { 2018)(Rauniar, et al., 2014) }\end{array}$} & \multirow[t]{4}{*}{0.747} \\
\hline & & $\begin{array}{l}\text { The content about different brands } \\
\text { shared by my friends on Facebook } \\
\text { persuades me to react (like or dislike or } \\
\text { love or angry, etc.) upon. }\end{array}$ & & \\
\hline & & $\begin{array}{l}\text { Content or advertisements of different } \\
\text { brands on Facebook allures me to share it } \\
\text { with my friends. }\end{array}$ & & \\
\hline & & $\begin{array}{l}\text { These brand pages encourages me to post } \\
\text { user generated content (comments, } \\
\text { mentions, reviews, posts, etc.)on } \\
\text { Facebook. }\end{array}$ & & \\
\hline \multirow[t]{3}{*}{2} & \multirow[t]{3}{*}{ Trust } & $\begin{array}{l}\text { Irust the information (ratings or } \\
\text { reviews) shared with me about the brand } \\
\text { through my friends on Facebook. }\end{array}$ & \multirow[t]{3}{*}{$\begin{array}{l}\text { (Wang \& Gulara Abdullayeva, } \\
\text { 2011) }\end{array}$} & \multirow[t]{3}{*}{0.819} \\
\hline & & $\begin{array}{l}\text { Brands show casing their content on } \\
\text { Facebook News Feed are more credible. }\end{array}$ & & \\
\hline & & $\begin{array}{l}\text { A sense of loyalty is felt for the } \\
\text { companies I know via Facebook. }\end{array}$ & & \\
\hline \multirow[t]{6}{*}{3} & \multirow[t]{6}{*}{$\begin{array}{l}\text { Performance } \\
\text { Expectancy }\end{array}$} & $\begin{array}{l}\text { Facebook brand pages supplies relevant } \\
\text { product information like reviews, likes/ } \\
\text { dislikes, etc. that assists in making } \\
\text { purchase decision for any product. }\end{array}$ & \multirow[t]{6}{*}{$\begin{array}{l}\text { (Alalwan, 2018)(Venkatesh, et } \\
\text { al., 2012) }\end{array}$} & \multirow[t]{6}{*}{0.889} \\
\hline & & $\begin{array}{l}\text { Facebook brand pages are beneficial } \\
\text { while considering any product for } \\
\text { purchase decision as it allows me to refer } \\
\text { the opinion of experts and friends } \\
\text { (reviews). }\end{array}$ & & \\
\hline & & $\begin{array}{l}\text { Contents on Facebook brand pages are } \\
\text { valuable source of up-to-date product } \\
\text { information. }\end{array}$ & & \\
\hline & & $\begin{array}{l}\text { Facebook brand pages benefits me in } \\
\text { better decision making as brand } \\
\text { engagement reduces my risk. }\end{array}$ & & \\
\hline & & $\begin{array}{l}\text { It is interactive thus enables me to } \\
\text { communicate by giving direct connection } \\
\text { with the company. }\end{array}$ & & \\
\hline & & $\begin{array}{l}\text { Facebook brand pages allows me opinion } \\
\text { exchange with others customers and } \\
\text { friends. }\end{array}$ & & \\
\hline
\end{tabular}


Modeling the Relationship of Consumer Engagement and Brand Trust on Social Media Purchase Intention - A Confirmatory Factor Experimental Technique

\begin{tabular}{|c|c|c|c|c|}
\hline \multirow[t]{3}{*}{4} & \multirow[t]{3}{*}{ Purchase Intent } & $\begin{array}{l}\text { I will purchase the products promoted } \\
\text { through Facebook advertising. }\end{array}$ & \multirow[t]{3}{*}{$\begin{array}{l}\text { (Venkatesh, et al., 2012)(Duffett, } \\
\text { 2015)(Rauniar, et al., } \\
\text { 2014)(Alalwan, 2018)(Mueller, } \\
\text { et al., 2011). }\end{array}$} & \multirow[t]{3}{*}{0.834} \\
\hline & & $\begin{array}{l}\text { I have high intention to purchase } \\
\text { products promoted on brand pages } \\
\text { through Facebook advertising. }\end{array}$ & & \\
\hline & & $\begin{array}{l}\text { I am more likely to become customer of } \\
\text { companies promoted through Facebook } \\
\text { advertising. }\end{array}$ & & \\
\hline
\end{tabular}

Validity \&Reliability Test

The convergent, discriminate validity and reliability of the examined constructs were tested using maximum likelihood estimation method as shown below in Table II.The Composite
Reliability (CR), The Average Variance Extracted (AVE) \& Maximum Shared Variance (MSV) were within the thresholds (Nunnally \& Bernstein, 1994) confirming convergent validity (Hair, et al., 2010) and discriminate validity.

Table II (Reliability Analysis)

\begin{tabular}{|l|l|l|l|l|l|l|l|l|}
\hline & CR & AVE & MSV & MaxR(H) & PEREXP & ENGAGE & PURTINT & TRUST \\
\hline PEREXP & 0.890 & 0.574 & 0.547 & 0.894 & $\mathbf{0 . 7 5 8}$ & & & \\
\hline ENGAGE & 0.786 & 0.523 & 0.059 & 0.975 & $0.234 * * *$ & $\mathbf{0 . 7 2 3}$ & & \\
\hline PURTINT & 0.844 & 0.647 & 0.454 & 0.877 & $0.648^{* * *}$ & $0.220^{* * *}$ & $\mathbf{0 . 8 0 4}$ & \\
\hline TRUST & 0.791 & 0.561 & 0.547 & 0.820 & $0.740^{* * *}$ & $0.242^{* * *}$ & $0.674^{* * *}$ & $\mathbf{0 . 7 4 9}$ \\
\hline
\end{tabular}

After validation of the measurement model, ensuing Structural Equation Modeling (SEM) analyses were done, in order to test the hypotheses developed as well as to validate the theoretical model. The measurement model fit, the overall CMIN was 225.962 with Df $=93$ and CMIN/Df $=2.430$. The initial fit indices $(\mathrm{GFI}=0.955$, IFI $=0.974$, AGFI $=0.934$, $\mathrm{NFI}=0.957, \mathrm{CFI}=0.974$, and RMSEA $=0.048, \mathrm{RMR}=0.030$ ) of the measurement model were within their recommended level, and this depicts that the observed data adequately fits the measurement model(Hu \& Bentler, 1999). Thus, it was considered aptfor subsequent testing of the hypothesized paths.

\section{The Structural Model Evaluation and Testing of \\ Hypothesis}

The next step includes testing of structural model so as to validate the conceptual model. About $0.07,0.55$, and 0.51 of variance were accounted for in trust, performance expectancy and purchase intent respectively as shown in Figure 1.

It can be observed that, the relation amongst trust and purchase intent $(\gamma=0.44, \mathrm{p}<0.001)$ is significant (Table III and Figure 1). Similarly, path from performance expectancy to purchase intent recorded $(\gamma=0.32, \mathrm{p}<0.001)$. This implies that brandtrust and performance expectancy of social media brand pages significantly impacts thecustomer purchase intent.

Another path from trust to performance expectancy $(\gamma=0.74, p$ $<0.001)$, stating significant impact of brand trust on performance expectancy of social media brand pages (Table III and Figure 1).

The relation of Engagement on social media to trust $(\gamma=0.26$, $\mathrm{p}<0.001$ ) is also significant (Table III and Figure 1). Thus, Social mediaEngagement have a significantly affects the brand trust. Therefore, $\mathrm{H}_{01}, \mathrm{H}_{02}, \mathrm{H}_{03}$ and $\mathrm{H}_{05}$ could not be rejected. 
Figure 1 Confirmatory Factor Analysis Diagram

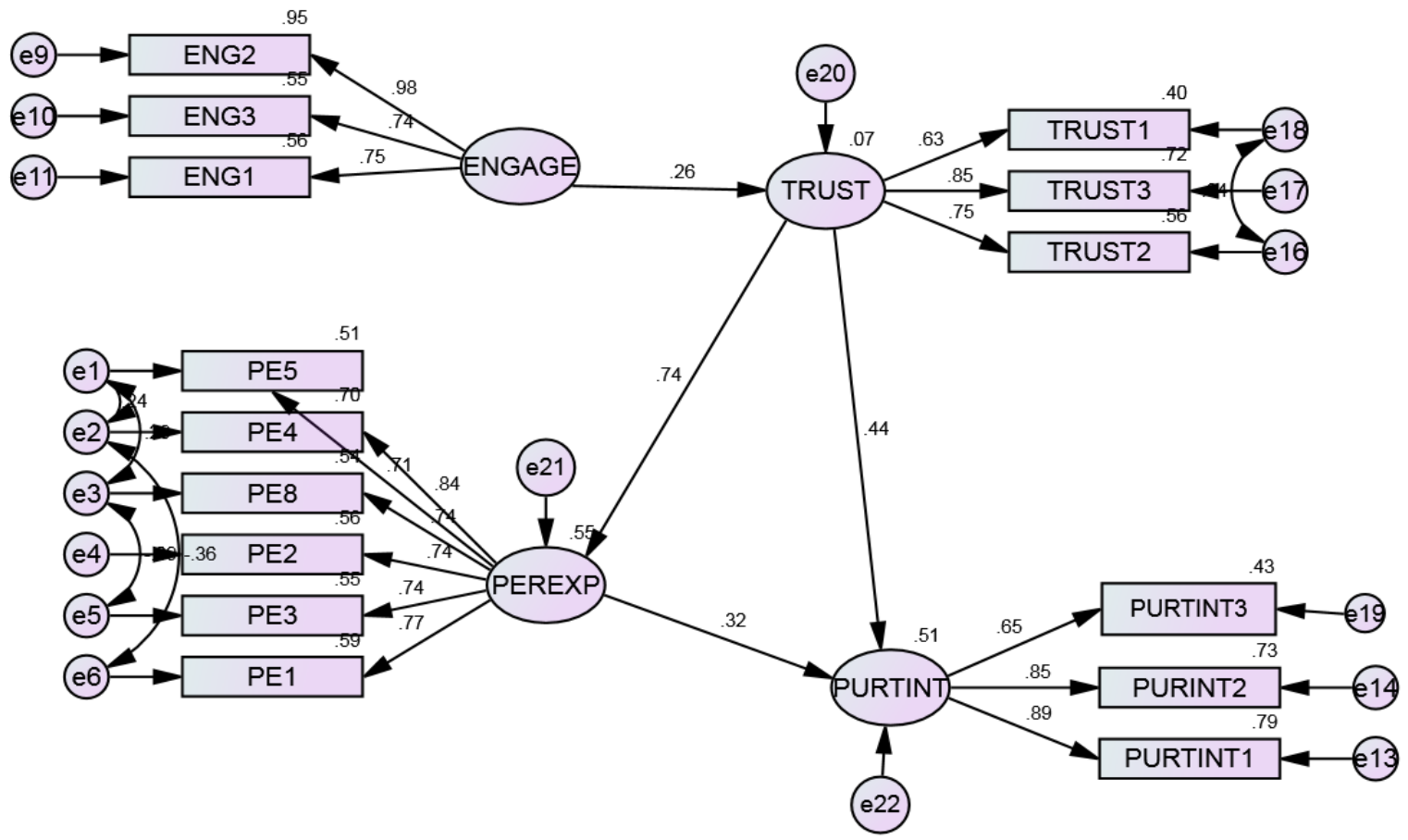

Table III (ModelRegression Weights)

\begin{tabular}{|c|c|c|c|c|c|c|c|}
\hline \multicolumn{2}{|c}{ Path } & $\begin{array}{c}\text { Unstandardized } \\
\text { Estimate }\end{array}$ & S.E. & C.R. & P & Standardized Estimates \\
\hline TRUST & $<---$ & ENGAGE & .174 & .030 & 5.864 & $* * *$ & .265 \\
\hline PEREXP & $<---$ & TRUST & .687 & .051 & 13.460 & $* * *$ & .745 \\
\hline PURTINT & $<---$ & TRUST & .497 & .077 & 6.435 & $* * *$ & .442 \\
\hline PURTINT & $<---$ & PEREXP & .389 & .079 & 4.894 & $* * *$ & .319 \\
\hline PE5 & $<---$ & PEREXP & 1.000 & & & & .715 \\
\hline PE4 & $<---$ & PEREXP & 1.076 & .050 & 21.648 & $* * *$ & .836 \\
\hline PE8 & $<---$ & PEREXP & .959 & .048 & 19.975 & $* * *$ & .735 \\
\hline PE2 & $<---$ & PEREXP & 1.023 & .059 & 17.349 & $* * *$ & .745 \\
\hline PE3 & $<---$ & PEREXP & .946 & .055 & 17.175 & $* * *$ & .744 \\
\hline PE1 & $<---$ & PEREXP & 1.114 & .064 & 17.417 & $* * *$ & .767 \\
\hline ENG2 & $<---$ & ENGAGE & 1.000 & & & & .977 \\
\hline ENG3 & $<---$ & ENGAGE & .727 & .036 & 20.207 & $* * *$ & .739 \\
\hline ENG1 & $<---$ & ENGAGE & .660 & .032 & 20.429 & $* * *$ & .746 \\
\hline PURTINT1 & $<---$ & PURTINT & 1.000 & & & & .888 \\
\hline PURINT2 & $<---$ & PURTINT & .959 & .039 & 24.336 & $* * *$ & .852 \\
\hline TRUST2 & $<---$ & TRUST & 1.000 & & & & .751 \\
\hline TRUST3 & $<---$ & TRUST & 1.205 & .067 & 17.960 & $* * *$ & .846 \\
\hline TRUST1 & $<---$ & TRUST & .726 & .041 & 17.775 & $* * *$ & .629 \\
\hline PURTINT3 & $<---$ & PURTINT & .700 & .040 & 17.615 & $* * *$ & .653 \\
\hline
\end{tabular}

4.4 Testing of Mediating Effect of Performance Expectancy in Relation of Trust to Purchase Intent

The model fitness is realized (CMIN /DF 1.465, $\mathrm{P}=.233$, $\mathrm{RMSEA}=.027 \mathrm{RMR}=.012, \mathrm{GFI}=.998, \mathrm{AGFI}=.988, \mathrm{NFI}=$ .998$, RFI $=.993$, IFI $=.999$, CFI $=.999)$, and all the standardized path coefficients are statistically significant (Figure 1). As the first criterion of Baron and Kenny's is met, therefore, the mediation test can be applied.
In order to test the role of mediation, a two-step process was followed. The first step determines inter-relationship amongst independent (Trust) and dependent (Purchase Intent) construct. The $\mathrm{r}^{2}$ is 0.58 , which is a good relation criteria and is statistically significant as $\mathrm{p}>.001$ as per Table IV and Figure 2. 
Modeling the Relationship of Consumer Engagement and Brand Trust on Social Media Purchase Intention - A Confirmatory Factor Experimental Technique

Figure 2 Confirmatory Factor Analysis Diagram with no Mediation

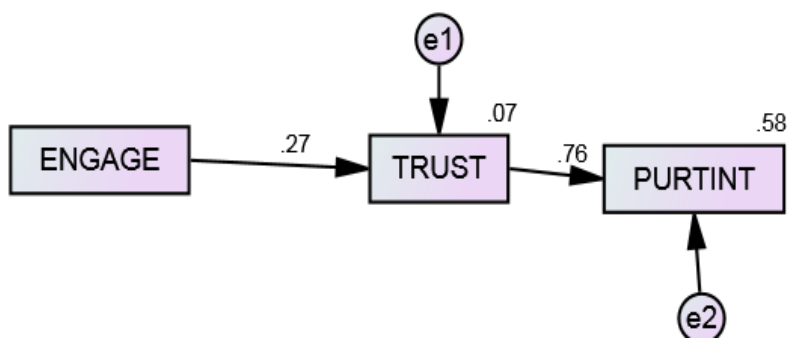

Table IV (Regression Weights of Trust on Purchase intent with no mediations)

\begin{tabular}{|lll|lllll|}
\hline Path & & & Estimate & S.E. & C.R. & P & $\mathrm{r}^{2}$ \\
\hline PURTINT & $<---$ & TRUST & 0.875 & .030 & 29.101 & $* * *$ & 0.577 \\
\hline
\end{tabular}

Further, the relation was tested in presence of mediator.

For this purpose, bias-corrected bootstrap method was used to generate 2,000 bootstrap samples at 95 percent confidence interval (Hayes \& Andrew , 2013).A model was created in which the role of trust in performance expectancy (mediation) was revealed significant as the p-value was 0.001 at point estimate of 0.787 . Similarly, the role of performance expectancy mediation in purchase intent was also established significant (p-valueis 0.001)(point estimate0.317). Besides, the role of trust in purchase intent was found significant (p-value 0.001) (point estimate 0.626) as shown in Table V and Figure 3. The bias corrected lower and upper confidence intervals are 0.159 and 0.331 (with no zero in between) which depicts that performance expectancy mediates the relationship between trust and purchase intent. The total effect of 0.875 is significant (p-value 0.001)as well as direct effect of 0.626 ( $p$-value 0.001 ) is also significant. The standardized indirect effect was also established significant (with p-value 0.001 ) at point estimate 0.271 .

\section{Figure 3 Confirmatory Factor Analysis Diagram with Mediation}

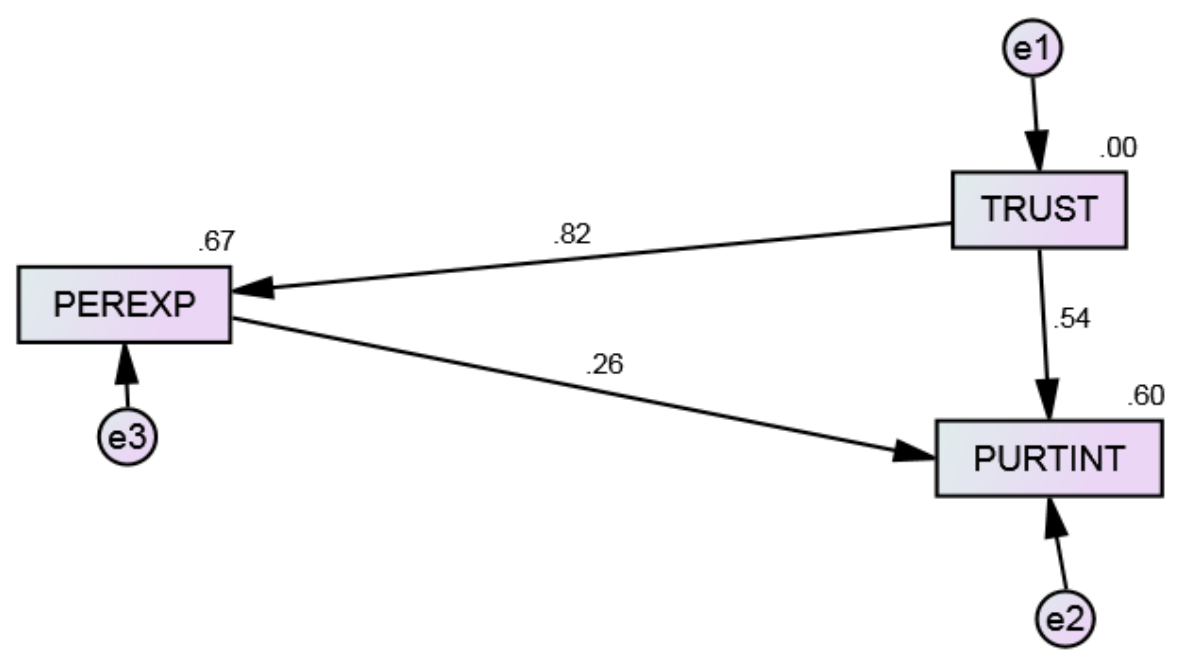

As the $\mathrm{p}$ value of the Two-Tailed Significance $(\mathrm{BC})$ test is 0.001 , so it is also significant. This evidences presence of significant mediation (Table VI), which fulfils two basic assumptions of mediation. The type of mediation is partial mediation (Baron \& Kenny, 1986) as the effect is still significant after the presence of mediation ( $p$ value is 0.001 )
(Table V) although the relation or beta is reduced from 0.76 to 0.54

Thus, the hypothesis $\mathrm{H}_{04}$ is not rejected and this implies that, Performance Expectancy of Brand Pages partially mediates the inter-relationship amongst trust and purchase intent. 
Table V (Relation of identified variables after mediation)

\begin{tabular}{|l|l|l|l|l|l|l|l|}
\hline & & & Estimate & S.E. & C.R. & P & Label \\
\hline TRUST & $<---$ & ENGAGE & .161 & .023 & 6.884 & $* * *$ & \\
\hline PEREXP & $<---$ & TRUST & .787 & .022 & 35.775 & $* * *$ & \\
\hline PURTINT & $<---$ & TRUST & .626 & .051 & 12.227 & $* * *$ & \\
\hline PURTINT & $<---$ & PEREXP & .317 & .053 & 5.945 & $* * *$ & \\
\hline
\end{tabular}

Table VI (Indirect Effects - Two Tailed Significance (BC))

\begin{tabular}{|l|lll|}
\hline & ENGAGE & TRUST & PEREXP \\
\hline TRUST & $\ldots$ & $\ldots$ & $\ldots$ \\
PEREXP & .001 & $\ldots$ & $\ldots$ \\
PURTINT & .001 & .001 & $\ldots$ \\
\hline
\end{tabular}

\section{CONCLUSIONS, DISCUSSIONS AND IMPLICATIONS}

The current study borrows construct form the Unified Theory Of Acceptance And Use Of Technology (UTAUT) model(Venkatesh, et al., 2012) and integrates them with the relation of Trust and Engagement on social media. It then tests this integrated model and examines the relations of these factors that affect the purchase intentions on social media. Previous researches has tended to overlook the mediating role of performance expectancyalthough they tried to establish intense, profound, devoted and significant relationships(Hajli, 2014)and a close link(David, et al., 2008) between a brand and its customers.As deliberated by(Alalwan, 2018) and (Shareef, et al., 2017), marketing strategies on social media should be targeted towards gaining attention of customers. Accordingly, extensive review of literature leads the study to identify three main factors (engagement, trust, and performance expectancy) as strategic predictors of the purchase intention.

The paradigm deliberated by the researchers offer new insights for both research and managerial implications. Firstly, Push marketing does not work on social media else engagement is the key policy(Hanke, 2015)(Alalwan, 2018). Hence, effective content creation and steady interaction (such as Conducting Facebook Live Chat) with consumers will entice them. Secondly, enriched engagement helps to upsurge the brand trust(Chahal \& Rani, 2017)(Angella Jiyoung Kim, 2010)which invigorates the performance expectancy of these brand pages on social media(David, et al., 2008). Lastly, the study established a positive partial mediating relation of performance expectancy of brand pages in relation of brand trust and consumer social media purchase intention. This means that brand trust has a direct relation with purchase intention and more trust increases performance expectancy of Facebook brand pages, which directly effects again purchase intention. Thus marketers must design strategies so as to increase the trust, performance expectancy and finally contributes toward bottom line.

Social media interactivity is the main source of performance expectancy of consumers. Accordingly, by leveraging this interactivity i.e. by conducting opinion polls or live demos or

crowdsourcing or involving large numbers of people to generate ideas, or asking to suggest improvements through adding recommendation box will not only increase performance expectancy but also enrich their trust towards the brand.

Hence, the brand pages shall deliver an unswerving quality of experience to consumers. To conclude, marketers should design strategies that first convert the customers to brand enthusiasts and then brand trusty and finally brand envoys.

\section{Limitations AND ScOPE OF FUTURE STUdy}

Although the study inference the key relations of factors affecting social media marketing strategies, the study still presents some limitations. Certain personality traits (tech-enthusiasm, concern for privacy, creativity of the message) and demographic factors (income level, educational level, occupation, etc.) are not deliberated in the research. Thus, it mindfulness to such aspects would be worthwhile for the future studies. Qualitative methods and techniques like content analysis, sentiment analysis providing an extensive view about the customer's attitude, engagement, and behavior towards these ads. This research has not studied social media advertisements over numerous other social media channels (i.e. YouTube, Twitter and Pinterest, etc.) future studies may take other specific or all of these platforms in account and gather data from their members. Thus, analysis of different channels, its nature and exploring how these factors acts inversely in different platforms, is a future scope of study.

\section{REFERENCES}

1. Gaskin, J. \& Lim, J., 2016. "Master Validity Tool" AMOS Plugin, s.1.: s.n.

2. Sanzo, M., Santos,, M., García, N. \& Trespalacios, J., 2012. Trust as a moderator of the relationship between organizational learning and marketing capabilities: Evidence from Spanish SMEs.. International Small Business Journal, 30(6), pp. 700-726.

3. Alalwan, A. A., 2018. Investigating the impact of social media advertising features on customer purchase intention. International Journal of Information Management, pp. 66-77. 


\section{Modeling the Relationship of Consumer Engagement and Brand Trust on Social Media Purchase Intention - A Confirmatory Factor Experimental Technique}

4. Alalwan, A., Rana, N. \& Algharabat, R. \&. T., 2016. A systematic review of extant literature in social media in the marketing perspective.. s.1., s.n., pp. 79-89.

5. Ali, H., 2011. Exchanging value within individuals' networks: social support implications for health marketers. Journal of Marketing Management, 27(3/4), pp. 316-335.

6. Al-Omari, H. a. A.-O. A., 2004. A framework model for assessment of e-Government readiness: Building an e-Government e-Trust Infrastructure.. Amman, Jordan, s.n.

7. Angella Jiyoung Kim, \&. E. K., 2010. Impacts of Luxury Fashion Brand's Social Media Marketing on Customer Relationship and Purchase Intention. Journal of Global Fashion Marketing, pp. 164-171.

8. Anon., 2017. s.1.: statista.com.

9. Balakrishnan, J. \& Manickavasagam, J., 2013. Examining Beliefs Towards Social Media Advertisements Among Students and Working Professionals: An Application of Discriminant Analysis. Volume 7, pp. 697-705.

10. Ballantine, P. W. \& Stephenson, R. J., 2011. Help me, I'm fat! Social support in online weight loss networks. Journal of Consumer Behaviour, pp. 332-337.

11. Baron, R. \& Kenny, D., 1986. The moderator-mediator variable distinction in social psychological research: Conceptual, strategic, and statistical considerations. Journal of Personality and Social Psychology, 51(6), pp. 1173-1182.

12. Ba, S. \& Pavlou, P., 2002. Evidence of the effect of trust building technology in electronic markets: price premium and buyer behvior. MIS Quarterly, 26(3), pp. 243-268.

13. Benson, V., Filippaios, F. \& Morgan, S., 2010. Online social networks: Changing the face of business education and career planning. International Journal of e Business Management, 4(1), pp. 20-33.

14. Bhargava, R., 2006. typepad.com. [Online]

15. Available

www.rohitbhargava.typepad.com/webblog/2006/08/5_rules_of_soci.ht $\mathrm{ml}$

16. [Accessed Aug 2018].

17. Bolton, R. et al., 2013. Understanding Generation Y and their use of social media: a review and research agenda. Journal of Service Management, 24(3), pp. 245-267.

18. Castaldo, S., Premazzi, K. \& Zerbini, F., 2010. The meaning(s) of Trust. Content Analysis on the Diverse Conceptualizations of Trust in Scholarly Research on Business Relationship.. Journal of Business Ethics, Volume 96, p. 657-668.

19. Chahal, H. \& Rani, A., 2017. How Trust Moderates Social Media Engagement and Brand Equity?. Journal of Research in Interactive Marketing 11(3), pp. 312-335.

20. Chang, Y., Yu, H. \& Lu, H., 2015. Persuasive messages, popularity cohesion, and message diffusion in social media marketing. Journal of Business Research, Volume 68, p. 777-782.

21. Chaudhuri, A. \& Holbrook, M. B., 2001. The chain of effects from brand trust and brand affect to brand performance: The role of brand loyalty. Journal of Marketing, 65(3), pp. 81-93.

22. Chen, Y., Fay, S. \& Wang, . Q., 2011. The role of marketing in social media: how online consumer reviews evolve. Journal of Interactive Marketing, 25(2), pp. 85-94.

23. David, G., Karahanna, E. \& Detmar, W. S., 2008. Trust and TAM in Online Shopping: An Integrated Model. MIS Quaterly, March, 27(1), pp. $51-90$.

24. De, V., Gensler, L., Leeflang, S. 8. \& ES.H., 2012. Popularity of brand posts on brand fan pages: an investigation of the effects of social media marketing. Journal of interactive Marketing, 26(2), pp. 83-91.

25. Duffett, R. G., 2015. Facebook advertising's influence on intention-to-purchase and purchase amongst Millennials.. Internet Research, 25(4), p. 498-526.

26. EY, 2016. Social media marketing India trends study: Insight sfrom social media-savvy brands in India., s.l.: s.n.

27. Ferik, M., 2009. Sue Scheff: 2010 Social Media Predictions by Michael Fertik. s.1.:suescheff.wordpress.com.

28. Guo, Y. \& Barnes, S., 2007. Why people buy virtual items in virtual worlds with real money. The DATA BASE for Advances in Information Systems, 38(4), pp. 69- 76.

29. Hair, J. et al., 2010. Multivariate data analysis. 7 ed. Upper Saddle River, NJ: Prentice Hall, New York.: Pearson.

30. Hajli, N., 2014. A study of the impact of social media on consumers. International Journal of Market Research •, pp. 388-404.

31. Hanke, M., 2015. How Luxury Fashion Brands Utilize YouTube to Engage Consumers and Promote Brand Identity. The Elon Journal of Undergraduate Research in Communications, Vol. 6,( No. 1), pp. 69-77.

32. Hayes \& Andrew , F., 2013. Introduction to mediation, moderation, and conditional process analysis: A regression-based approach. New York: The Guilford Press.

33. Henderson, R. \& Megan, . J. D., 2003. Perceived usefulness, ease of use and electronic supermarket use. International Journal of Human Computer Studies, Volume 59, pp. 385-395.

34. Hollebeek, L., Glynn, M. \& Brodie, R., 2014. Consumer brand engagement in social media: Conceptualization, scale development and validation. Journal of interactive marketing, pp. 149-165.

35. Hu, L. \& Bentler, P., 1999. Cutoff criteria for fit indexes in covariance structure analysis: Conventional criteria versus new alternatives. Structural equation modeling: a multidisciplinary journal, 6(1), pp. $1-55$.

36. Jyh-Jeng, W., Chen, Y.-H. \& Chung, . Y.-S., 2010. Trust factors influencing virtual community members: a study of transaction communities. journal of Business Research, 63(9-10), pp. 1025-1032.

37. Kim, T., Atkin, D. \& Lin, C., 2016. The Influence of Social Networking Sites on Political Behavior: Modeling Political Involvement via Online and Offline Activity. Journal of Broadcasting \& Electronic Media, Volume 60, pp. 23-39.

38. Kotler, P. P. W., 2006. B2B brand management. Berlin: Springer.

39. Lee, J.-H. \& Song, C.-H., 2013. Effects of trust and perceived risk on user acceptance of a new technology service. Social Behavior And Personality: An international journal, 41(4), pp. 587-598.

40. Linlin, L., Matthew , K., Renjing, L. \& Jiawen, 2018. Trust transfer in social media brand communities: The role of consumer engagement. International Journal of Information Management, pp. 1-13.

41. Liu, D. \& Guo, X., 2017. Can trust and social benefit really help? Empirical examination of purchase intentions for wearable devices. Information Development SAGE, 33(1), pp. 43-56.

42. Lu, H. \& Hsiao, K., 2010. The influence of extro/introversion on the intention to pay for social networking sites. Information \& Management, 47(3), pp. 150-157.

43. Mayer, P., Volland, D., Thiesses, F. \& Fleisch, E., 2011. User Acceptance of 'Smart Products': An Empirical Investigation. s.1., s.n., p. Paper 9.

44. McLeod, A., Pippin, S. \& Mason, R., 2008. Individual taxpayer intention to use tax preparation software: Examining experience, trust, and perceived risk. s.1., s.n.

45. Mueller, J., Hutter, K., Fueller, J. \& Sc Matzler, K., 2011. Virtual worlds as knowledge management platform - a practice-perspective. Information Systems Journal, 21(6), pp. 479-501.

46. muller, J., Fueller, K. \& J. Sc Matzler, K., 2011. Information Systems Journal, pp. 479-501.

47. Nelson, S., 2018. Digital Doughnut. [Online]

48. Available https://www.digitaldoughnut.com/articles/2018/february/7-reasons-wh y-social-media-marketing-is-important

49. [Accessed 2018].

50. Nunnally, J. \& Bernstein, I., 1994. Psychometric Theory. New York: McGraw-Hill.

51. Pavlou, P. A., 2003. Consumer Acceptance of Electronic Commerce: Integrating Trust and Risk with the Technology Acceptance Model. International Journal of Electronic Commerce, 59(4), pp. 69-103.

52. Rana, N., Dwivedi, Y., Williams, M. D. \& We, 2016. Adoption of online public grievance redressal system in India: Toward developing a unified view. Computers in Human Behavior, Volume 59, p. 265-282.

53. Rauniar, R., Rawski, G., Yang, J. \& Johnson, B., 2014. Technology acceptance model(TAM) and social media usage: an empirical study on Facebook. Journal of Enterprise Information Management, pp. 6-30.

54. Reichheld, F., 2006. The Ultimate Question: Driving Good Profits and True Growth. Boston, MA: Harvard Business School Press.

55. Riemenschneider, C. K. J. a. L. L., 2009. Web trust-A moderator of the web's perceived individual impact.. Journal of Computer Information Systems, 49(4), pp. 10-18.

56. Roberts, C. \& Alpert, F., 2010. Total customer engagement: designing and aligning key strategic elements to achieve growth. Journal of Product \& Brand Management, 19 (3), pp. 198-209.

57. Sashi, C., 2012. Customer engagement, buyer-seller relationships, and social media. Journal of Management History, Volume Vol. 50, No. 2, pp. 253-272.

58. Shareef, M. A., Dwivedi, Y. K., Kumar, V. \& Kumar, 2017. Content design of advertisement for consumer exposure: Mobile marketing through short messaging service. International Journal of Information Management, 37(4), pp. 257-268. 
59. statista, 2018. Most popular network worldwide, s.1.: s.n.

60. Swaminathan, V., Page, K. L. \& Rhan-Canli, Z. G., 2007. "My” Brand or "Our" Brand: The Effects ofBrand Relationship Dimensions and SelfConstrual on Brand Evaluations. Journal Of Consumer Research, Volume 34, pp. 248-259.

61. Tan Pei Kian, G. H. , 2017. Factors That Influence the Consumer Purchase Intention in Social Media Websites. Int. J Sup. Chain. Mgt, 6(4), pp. 208-214.

62. Venkatesh, V., Morris, M. G. \& Davis, G., 2003. User Acceptance of Information Technology: Toward a Unified View. MIS Quarterly, 27(3).

63. Venkatesh, V., Thong, J. Y. \& Xu, X., 2012. Consumer acceptance and use of information technology: Extending the unified theory of acceptance and use of technology.. MIS Quarterly, 36(1), p. 157-178.

64. Victor A. Barger, J. W. P. E. S., 2016. Social media and consumer engagement: A review and research agenda. Journal of Research in Interactive marketing, pp. 2668-287.

65. Victor, A. B. \& J. W. , 2016. Social media and consumer engagement: A review and research agenda. Journal of Research in Interactive marketing, pp. 2668-287.

66. Wang, C. \& Tong, H., 2010. Factors Influencing Consumer Intention In Social Commerce Adoption. Washington, DC, USA, IEEE Computer Society, pp. 2105-2108.

67. Wang, X. \& Gulara Abdullayeva, 2011. The Relationship Between Use of Social Media and Customer Relationship From E-commerce Model Perspective. lund: Department of Informatics, Lund University.

68. Yoo, K.-H. \&. G. U., 2012. Use and creation of social media by travellers. In: Social Media in Travel, Tourism and Hospitality: Theory, Practice and Cases. s.1.:s.n., pp. 189-205.

69. Zhang, H., Lu, Y., Gupta, S. \& Zhao, L., 2014. What motivates customers to participate in social commerce? The impact of technological environments and virtual customer experiences. Information Management, 51(8), p. 1017-1030. 